\title{
MOŻLIWOŚĆ ZASTOSOWANIA TEORII DECYZJI DO ZAGADNIEŃ ETYCZNYCH W UJĘCIU KLEMENSA SZANIAWSKIEGO
}

\begin{abstract}
Streszczenie. Klemens Szaniawski, mimo że kojarzony z filozofią nauki i logiką, w swoich rozważaniach zajmuje się również teorią decyzji i wskazuje na jej związek z zagadnieniami etycznymi. Wychodząc od pojęciowego i językowego powiązania między teorią decyzji a etyką, poszukuje dalszych ich relacji, które poddaje analizie.

W artykule pokazano przydatność twierdzeń teorii decyzji nie tylko do analizy zagadnień etycznych, ale także wyborów działania (podejmowania decyzji), które ściśle są związane z podmiotem etycznym. Po pierwsze, wskazano, że pojęcie racjonalności jest istotnym elementem wiążącym proces decyzyjny z etyką. Po drugie, pojęcie decyzji zawiera dwa elementy: wybór działania i postanowienie jego realizacji. Decyzja jest zrelatywizowana do celu, cel zaś determinuje działanie podmiotu, a sam wybór uwzględnia przekonania i wartościowanie decydenta. Po trzecie, rozumienie pojęcia decyzji wiąże się z podmiotem, który posiada pewien charakter i formuje go podczas podejmowania decyzji. Co więcej, w konkretnych decyzjach podmiotu, uwidoczniają się jego cele, środki i motywy. Dlatego włączenie teorii decyzji do analizy osobowości podmiotu i definiowania tożsamości pozwala na uzyskanie wielostronnej wiedzy na temat człowieka.

W nowym spojrzeniu na zagadnienie całego procesu decyzyjnego wskazano na możliwość pragmatycznego zastosowania pojęć teorii decyzji w etyce. By określić przydatność aparatury pojęciowej teorii decyzji w praktyce, posłużono się przykładami zaczerpniętymi z nauk prawnych i medycyny.
\end{abstract}

Słowa kluczowe: decyzja, teoria decyzji, etyka, racjonalność, zastosowanie decyzji w etyce, decyzja jako wartość, podmiot etyczny

1. Wprowadzenie. 2. Racjonalność i etyka. 3. Proces decyzyjny w kontekście etycznym. 4. Przykłady zastosowania aparatu teorio-decyzyjnego do zagadnień etycznych. 5. Zakończenie. 


\section{WPROWADZENIE}

Klemens Szaniawski (1925-1990) był filozofem z kolejnego pokolenia naukowców szkoły lwowsko-warszawskiej. Był kontynuatorem tradycyjnego etosu inteligencji polskiej zaczerpniętego od swoich nauczycieli: Jana Łukasiewicza, Tadeusza Kotarbińskiego, Kazimierza Ajdukiewicza oraz Marii i Stanisława Ossowskich, co znaczy, że łączył powołanie zawodowe naukowca z postawą zaangażowania się w sprawy kraju. Jego zainteresowania naukowe, choć mocno zróżnicowane i zmieniające się na przestrzeni lat jego kariery naukowej, zawsze były rzetelnie realizowane. Szaniawski, udzielając wywiadu, mówi: „nie jestem z tych, co od samego początku wiedzieli, co ich interesuje. I że właśnie to, a nie nic innego. Mnie mnóstwo rzeczy interesowało. Zupełnie przeciwległych: i filologia, i matematyka. Nawet studiowałem matematykę. No, a potem filozofię. A że w tej filozofii to miałaby być w szczególności logika, tego długo jeszcze nie wiedziałem. Zajmowałem się etyką. Byłem nawet do 1952 roku asystentem Marii Ossowskiej"1.

Szaniawski został logikiem, ale w szerszym tego słowa znaczeniu. Terenem jego aktywności naukowej była metodologia nauk, a przede wszystkim problematyka uznawania zdań. Ze wstępu, napisanego przez Stefana Amsterdamskiego i Jana Woleńskiego, do obszernej monografii dzieł Szaniawskiego pt. O nauce, rozumowaniu $i$ wartościach czytamy: „Z jednej strony, Szaniawski był uczniem filozofów (...) przekonanych o obiektywności nauki (...). Z drugiej jednak strony Profesor Szaniawski był zwolennikiem teorii funkcji

1 Jak wywiad, to wywiad..., red. I. Heppen, A. Negri, Przegląd Filozoficzny - Nowa Seria 20(2011)2(78), 298. Rozmowa nagrana 18 czerwca 1979 roku jest zapisem audycji radiowej w II Programie Polskiego Radia. W audycjach tych znane osoby, skojarzone w pary, przeprowadzały ze sobą nawzajem wywiady. W tej audycji były nimi Klemens Szaniawski i Andrzej Łapicki. 
decyzji, ideowo uwzględniającej elementy subiektywne w poznaniu i działaniu"'.

Ten krótki wstęp biograficzny charakteryzuje osobę Klemensa Szaniawskiego jako uczonego, który mimo wybitnych osiągnięć $\mathrm{w}$ dziedzinie statystyki i logiki, był wierny etyce ${ }^{3}$. W jego pracach przebija się owo zainteresowanie wartościami i postawami moralnymi. Pokazuje on praktyczny wymiar tychże zasad i wzorów, głównie w odniesieniu do teorii decyzji.

\section{RACJONALNOŚĆ I ETYKA}

Szaniawski szczególną uwagę poświęcał racjonalności: doszukiwał się jej w logice, prakseologii i teorii decyzji, ale także w etyce. „Interesował się możliwościami racjonalnego rozstrzygania sporów etycznych, był bowiem przekonany - wbrew naiwnemu naturalizmowi - że chociaż wartościowanie jest nie do uniknięcia, to jednak - wbrew radykalnemu emotywizmowi - daje się, przynajmniej częściowo »ważyć« za pomocą intersubiektywnych standardów”. Każdy wybór jest inny. Nie jest istotne jak dokonuje się wyboru, ale aby decydent zdawał sobie sprawę, przy wyborze danego kryterium podejmowania decyzji, że każda metoda ma różne własności i konsekwencje. Najwygodniej byłoby mieć dla wszystkich decydentów jeden sposób wartościowania informacji, będący wytyczną racjonalnego podejmowania decyzji. Jednak tak się nie dzieje, ponieważ porównując różne sposoby podejmowania decyzji, informacja musi, po pierwsze, mieć pierwiastek dowolności, a po drugie, musi reglamentować wszelkie wiadome ze względu na praktyczną stosowalność.

2 S. Amsterdamski, J. Woleński, Wstęp, w: K. Szaniawski, O nauce, rozumowaniu i wartościach, wybrał i opracował J. Woleński, Warszawa 1994, XVI.

3 Pracę magisterską na temat moralistyki francuskiej przełomu XVII i XVIII wieku napisał u M. Ossowskiej. Doktoryzował się w roku 1950 na temat Analiza pojęcia honoru na tle grup rycerskich Europy Średniowiecznej.

4 S. Amsterdamski, J. Woleński, dz. cyt., XIII-XIV. 
Szaniawski zauważa, że często metody działania decydenta upodabniają się do strategii w teorii gier. Wynika to $z$ tego, że metoda działania zależna jest od okoliczności podejmowania decyzji. A obie, metoda i okoliczności, mogą być skomplikowane. Formalnie metoda jest funkcją, w praktyce jest pewną formą przyjmowanych przez decydenta wyborów. „Postanowienie zrobienia czegoś lub lepiej zachowania się w określony sposób. Zachowanie jest tu rozumiane bardzo szeroko, obejmuje bowiem wstrzymanie się od działania, złożony łańcuch prostych działań, »strategie« w sensie teorii gier lub nawet przyjęcie czysto myślowej postawy (np. akceptacja pewnego punktu widzenia) $)^{5 "}$. Pośrednio decyzję można zdefiniować jako akt wyboru, gdzie decyzję charakteryzuje się poprzez istnienie zbioru (najmniej dwuelementowego - czyli tzw. działania), w stosunku do którego ów wybór się podejmuje przez decydenta ${ }^{6}$. „Pojęciem podstawowym jest problem decyzji definiowany przez Szaniawskiego jako trójka $<\mathrm{A}, \mathrm{S}, u>$, gdzie $\mathrm{A}=\left\{\mathrm{a}_{1}, \mathrm{a}_{2}, \ldots, \mathrm{a}_{\mathrm{m}}\right\}$ to skończony zbiór możliwych do podjęcia działań; $\mathrm{S}=\left\{\mathrm{s}_{1}, \mathrm{~s}_{2}, \ldots, \mathrm{s}_{\mathrm{n}}\right\}$ to skończony zbiór możliwych stanów rzeczy, od których zależą skutki działań; $u$ to funkcja wartościująca skutki, nazywana użytecznością?". Jednak wybór to nie wszystko. Jakie są przyczyny powstawania decyzji? Czy jest to raczej jakiś motyw przewodni naszego ciągu logicznego? Czy wynika to z jakiegoś chcenia - ze względu na nas samych, czy jakieś zewnętrzne okoliczności, bądź skutki? Czy tylko wtedy? Czym jest kierowany cały proces decyzyjny? W jakim stopniu kształtuje on moralność człowieka?

Rozważając te wątpliwości, Szaniawski twierdzi, że decyzja to coś więcej, „decyzja jest zarazem wyborem

5 K. Szaniawski, Filozofia podejmowania decyzji, w: tenże, O nauce, rozumowaniu i wartościach, dz. cyt., 432.

6 Tenże, Kryteria podejmowania decyzji, w: tamże, 286.

7 W. Gasparski, Klemensa Szaniawskiego teoria decyzji w zarysie, Prakseologia (2006)146, 16. 
i post a now i en i e m [podkreślenie moje - L.M.]" . Twierdzenie to zakłada, że istnieje pewna rozbieżność między tym, co wybraliśmy, a tym, jak działamy. Tym, co rzeczywiście zdecydowaliśmy wybrać jako najlepszą możliwość, a tym, co rzeczywiście wybraliśmy, sądząc, że jest to maksymalizacja wartości i przekonań. Przykładem może być sytuacja, gdzie pracodawca, w obliczu kryzysu, musi zwolnić pracowników. Do wyboru ma samotną matkę, wychowującą dwójkę dzieci, oraz kobietę po sześćdziesiątce, która w niedługim czasie może odejść na emeryturę. I jak postąpić? Posługując się skalą wartości, gdzie zysk jest ważny, pracodawca powinien zwolnić najsłabszą, najmniej „opłacalną” osobę. Natomiast jest jeszcze sfera wartości moralnych w tej decyzji, gdzie pracodawca musi brać pod uwagę dobro innych, swoje własne wartości, np. co do odpowiedzialności za życie innych ludzi. Jest to decyzja, która jednoznacznie nie ma rozwiązania, biorąc pod uwagę dwie różne skale wartości. Jednak, gdy pod uwagę brana jest tylko jedna skala, problem przestaje powodować trudności w rozwiązaniu. Szaniawski zakłada, że często decydujemy się na coś zupełnie innego, niż postanowiliśmy. Dlatego rozważanie kwestii ludzkich wyborów i zadawania pytania „dlaczego tak się dzieje?”, zbliża teorię decyzji do filozoficznych dociekań. Nie jest łatwe podejmowanie dobrych decyzji. Sama wiedza o tym, że dane rozwiązanie jest dobre, nie przysparza dobrego rozwiązania. A nawet właściwie dobrana skala wartości nie gwarantuje zamierzonego skutku.

Teoria decyzji wyjaśnia w różnych wariantach, co to znaczy wybierać racjonalnie w warunkach niedoskonałej wiedzy. „Pojęcie »racjonalnego wyboru « w problemie decyzji w warunkach niepewności jest na tyle nieprecyzyjne, że dopuszcza różne eksplikacje. Wprawdzie zostały sformułowane pewne postulaty racjonalnego wyboru, co umożliwia ocenę proponowanych eksplikacji pod rozmaitymi ich aspektami. Jednakże nie da się wszystkich tych postulatów uzgodnić

8 K. Szaniawski, Filozofia podejmowania decyzji, dz. cyt., 435. 
między sobą, toteż pozostaje wciąż kwestią indywidualnych preferencji, które z nich zostaną uznane za podstawowe"'. Dlatego Szaniawski pisze o racjonalności w podwójnie ograniczonym sensie.

Po pierwsze, decydent musi mieć pewną swobodę wyboru, ponieważ nie może istnieć jakieś jedyne rozwiązanie (z definicji niepełnej wiedzy). Choć w tej swobodzie Klemens Szaniawski dopuszcza swoistą arbitralność różnych form wyboru - np. skala wartościowania, cele, do których dążymy, są często zbieżne. Przykładem jest to, że każdy człowiek chce być szczęśliwy, ale dla każdego szczęście to może być różnie definiowane. „Wszelkie rozwiązanie problemu decyzji musi mieć w jakiejś mierze arbitralny charakter, a to $z$ uwagi na niekompletność wiedzy decydenta. Arbitralność ta przenosi się na wartościowanie informacji ${ }^{10}$ ". Wtedy pojęcie racjonalności zaczyna funkcjonować poza obszarem wspólnego wartościowania i obowiązuje w indywidualnych osądach.

Po drugie, pojęcie racjonalności w teorii decyzji jest formalne, czyli w odniesieniu do (indywidualnych) przekonań zajmuje się tylko ich niesprzecznością. Gdy chodzi o cele, w tym momencie zakłada je jako dane i nie podlegają one rozbiorowi ${ }^{11}$.

Wiąże się to $\mathrm{z}$ tym, że można wyróżnić dwa rozumienia racjonalności związanej z celem:

1. Racjonalność formalną - zrelatywizowaną względem celu. Racjonalność formalna zakłada cel jako daną nie podlegającą dalszemu rozbiorowi oraz zajmującą się tylko niesprzecznością przekonań, nie uwzględnia skal wartości podmiotu.

2. Racjonalność rzeczową - gdzie określamy wymagania względem celu. Taka wersja racjonalności towarzyszy modelom teorio-decyzyjnym - stąd też wiele wyników, dokonanych przez analizę

9 K. Szaniawski, Kilka uwag o kryterium racjonalnego podejmowania decyzji, w: tenże, O nauce, rozumowaniu i wartościach, dz. cyt., 187.

10 Tenże, Informacja a decyzja, w: tamże, 266.

11 Tenże, Filozofia podejmowania decyzji, dz. cyt., 443. 
tychże modeli, nie jest do zastosowania w praktyce, gdy oceniamy ludzkie działania uwzględniając ich cele. Dlatego też ciężko jest rozróżnić i określić pewną hierarchię wartości jednostki, przynajmniej używając pojęcia racjonalnego działania. Stąd też wynika trudność w rozróżnieniu przesądów, intuicji od „głosu rozsądku”, przekonań „racjonalnych”12.

Kluczem do zrozumienia pojęcia racjonalności w decyzji jest r ozumienie racjonalności jako wartości. Szaniawski poszukuje odpowiedzi na pytanie o rodzaj racjonalności, jaką uznajemy za wartośćc ${ }^{13}$. Czy też poszukuje jej miejsca w hierarchii wartości. „Pytanie dotyczy raczej tego, w jakim sensie racjonalność jest wartością i jaka racjonalność, niż - czy w ogóle nią jest ${ }^{14}$. Racjonalność jako wartość to najważniejsze spoiwo między decyzją a postępowaniem. Jest to pojęcie relatywne w każdej z dziedzin nauki, ponieważ każda $\mathrm{z}$ nich potrzebuje odniesienia $\mathrm{w}$ racjonalności, by była sensowna. Jednak relatywność racjonalności nie wpływa na jej rozumienie jako wartości naczelnej w nauce i kulturze współczesnej. „Działanie jest racjonalne wtedy, gdy jest skuteczne ze względu na cel. (...) Czyli: nie doraźny skutek rozstrzygałby o racjonalności, tylko zasada, którą kieruje się podmiot [podkreślenie moje - L.M.]. (...) Działanie może być skuteczne rzeczywiście lub też tylko w mniemaniu działającego. W pierwszym przypadku nazwiemy je racjonalnie obiektywne (lub rzeczowo), w drugim - subiektywnie (lub metodologicznie)15”. Wyróżnione przez Szaniawskiego rodzaje racjonalności wykorzystywane do opisu ludzkich zachowań,

12 Por. M. Blegvad, The Content and Status of Rationality Assumptions in Social Science, Danish Yearbook of Philosophy (1978)15, 56.

13 Zob. K. Szaniawski, Racjonalność jako wartość, Studia Filozoficzne (1983)210-211(5-6), 7-15. Artykuł w formie referatu został wygłoszony na konferencji Rozum - Racja - Racjonalność, zorganizowanej przez Komitet Nauk Filozoficznych PAN, 2-4 grudnia 1982 roku.

14 Tamże, 8.

15 Tamże, 10-11. 
to klasyczne rozumienie pojęcia racjonalności. Współcześnie ${ }^{16}$ to rozumienie jest inaczej postulowane. Przyjmuje ono, że pojęcie decyzji to akt wyboru, który zakłada zbiór możliwych zachowań, z których jedno tylko może zostać wybrane. Skutki nie są rozstrzygane, zależą od odmiennych czynników i nie mają wpływu na podmiot. Istotna jest treść wyboru jednostki i sam akt wyboru.

Zauważmy, że nastąpiła tu zasadnicza zmiana. W klasycznym ujęciu teoria decyzji nakierowana była na cel. (Można także dostrzec zmianę w rozważaniach Szaniawskiego - gdzie racjonalność, która kieruje do celu, była tą ważniejszą wobec samego podmiotu i jego zachowania.) We współczesnym podejściu liczy się przede wszystkim podmiot, cel jest dopełnieniem działania i decyzji o wyborze. Podmiot musi zdecydować o skutku, który najwyżej ocenia. Co więcej, racjonalność dla podmiotu przybiera formę racjonalności rzeczowej. W podmiocie zachodzi proces różnicowania wartości ze względu na skutki.

Racjonalność wyznacza pewien rodzaj pewności i stabilności. Nauka przecież powinna być stałym, niewzruszonym elementem budującym świat. W koncepcji Szaniawskiego decyzja, w powiązaniu z racjonalnością, w konkretnych sytuacjach wskazuje na działania i powiązane z nimi wartości, którymi kieruje się podmiot. Nie oznacza to zatem tylko racjonalnego (rozumowego) działania, ale wnosi dodatkowy czynnik - oceny działania i skutków podjętych działań. Zwrócona jest uwaga na istotność zachowań podmiotu i związku jego decyzji z kształtowaniem osobowości, poprzez selekcję wartości.

\section{PROCES DECYZYJNY W KONTEKŚCIE ETYCZNYM}

Stąd też warto przypomnieć koncepcję teorii decyzji, która w ujęciu Szaniawskiego stanowi integralną dziedzinę z praktyką ludzkich

16 Mówiąc 'współcześnie', mam na myśli lata 80. XX wieku, wtedy, gdy Szaniawski pisał artykuł. Jednak myślę, że współcześnie, w XXI wieku, niewiele się zmieniło w tej kwestii. 
wyborów. Co więcej, pewne reguły określane przez teorię decyzji mogą być oceniane w świetle wymogów dotyczących zagadnień etycznych. Chciałabym, idąc za Szaniawskim, wskazać „co etyk może uzyskać dzięki aparaturze pojęciowej teorii decyzji, a (...) czego uzyskać nie może"17. Sama decyzja etyczna, taka motywowana względami etycznymi, jest, jak twierdzi Szaniawski ${ }^{18}$, szczególnym przypadkiem decyzji w ogóle. Jednak chciałam także zwrócić uwagę na te elementy jego koncepcji, w których teoria decyzji styka się i z filozofią nauki, i z matematyką oraz logiką, i z etyką. „Gdyby rzecz ujmować najkrócej, to można powiedzieć, że postęp dokonany w filozofii nauki i przezwyciężanie jej kryzysu związane jest $\mathrm{z}$ wykształceniem się nowych, subtelnych narzędzi analizy, jakie logika - w szerokim rozumieniu - dostała do ręki. Chodzi tu przede wszystkim o teorię modeli, teorię decyzji i teorię informacji. (...) Teoria decyzji pozwala wyodrębnić na tyle, ile to możliwe, komponentę arbitralności w uznawaniu twierdzeń naukowych (we włączeniu ich w poczet tez akceptowanych na gruncie danej teorii). Pozwala ona lepiej zrozumieć mechanizm włączania nowych tez $\mathrm{w}$ poczet uznanych twierdzeń, rzuca nań nowe światło ${ }^{19}$. Filozofia nauki zyskała dzięki filozofii decyzji zupełnie nowy kontekst. Szaniawski pisząc o tym, rozważa dwa warunki, które musi spełnić teoria decyzji, aby uznać teorie naukowe. Po pierwsze, repertuar możliwości „do wyboru” musi być znany w pełni, musi być uświadomiony zupełnie. Po drugie, musi istnieć element oceny - odniesienia do celu postępu naukowego. Jednak cel nie jest łatwy do zrealizowania.

Powszechnie rozumiana prawda, do której przecież każdy naukowiec dąży, nastręcza mnóstwo problemów. Należy w tym momencie uwzględnić, że nie wszystkie poszczególne teorie w dążeniu do celu

17 K. Szaniawski, Teoria decyzji a etyka, Etyka (1967)2, 8.

18 Tamże, 7.

19 J. Syski, Czuwanie rozumu, Warszawa 1979, 81-82 (wywiad z Klemensem Szaniawskim z 1969 roku). 
jednakowo oceniamy. Stąd też konieczne jest spojrzenie na filozofię nauki jako szerszego konspektu, szerszego problemu, w którym teoria decyzji jest niezwykle istotnym elementem. Zastosowanie języka teorii decyzji do sfery filozofii nauki zbliża nas we wnioskach do przekonania, że teoria decyzji jest zbieżna również z innymi naukami.

Ogólne twierdzenia teorii decyzji Szaniawski rozważa przy analizie zagadnień etycznych w artykule pt. Teoria decyzji a etyka. Analizuje je w kontekście przydatności aparatury pojęciowej, zwracając uwagę na zagadnienie racjonalności. „Osobnik podejmujący decyzję (nazwiemy go decydentem) uprzytamnia sobie możliwe konsekwencje swych działań i potrafi je ocenić, nie wie jednak na pewno, która $\mathrm{z}$ tych konsekwencji się zrealizuje. Powstaje kwestia: jakie kryterium wyboru działania zasługuje na miano racjonalnego ${ }^{20 "}$. Co to właściwie znaczy racjonalny wybór? W tej kwestii Szaniawski od początku wyznacza pewne ścisłe rozumienie pojęcia racjonalność w kontekście teorii decyzji. „Spróbujmy sobie wyobrazić (...) co znaczy racjonalne kryterium podejmowania decyzji? Sam problem decyzji należy rozpatrywać w trzech aspektach. Otóż - istnieje pewien stan rzeczy (»stan świata w danych granicach), pewien repertuar możliwych zachowań (decyzji) i nasza ocena ich skutków. Można szukać rozmaitych kryteriów racjonalnego działania (...). Jednak (...) wszystkich postulatów nie sposób łącznie uwzględnić, bo są one po prostu sprzeczne ze sobą. Nie istnieje tedy możliwość ogólnego określenia kryterium racjonalności działania (...). Oto okazuje się, że w każdej decyzji istnieje nieuleczalna niedookreśloność, którą da się wyodrębnić $(\ldots)^{21 "}$. Tak rozumiana racjonalność nie jest bez znaczenia dla badaczy interesujących się zagadnieniami etycznymi. „Znany jest fakt, iż trudność, jaką sprawia wybór najlepszego w sensie moralnym działania, pochodzi co najmniej z dwóch źródeł: jednym z nich jest ocena skutków działania, drugim - niepewność tych skutków.

20 K. Szaniawski, Teoria decyzji a etyka, dz. cyt., 8.

21 J. Syski, dz. cyt., 84. 
Byłoby rzeczą pożądaną - z teoretycznego przynajmniej punktu widzenia - wyodrębnienie tych dwóch typów trudności w analizie wszelkiej decyzji. (...) wskazaniu, w jaki sposób postępować w warunkach niepewności lub ryzyka co do skutków działan - przy założeniu, że problem wartościowania tych skutków został pomyślnie rozstrzygnięty ${ }^{22 "}$.

Jak zatem właściwie rozstrzygnąć problem wartościowania w teorii decyzji? Szaniawski wskazuje, że liczbowe odniesienie do wartości jest przydatne w badaniu powiązań teorii decyzji i etyki, jednak jest mało dokładne i trudne do odniesienia. Bo jak liczbowo wyrazić daną wartość dla decydenta? Dlatego „wydaje się, iż w najlepszym razie wartościowaniom etycznym można by było przypisywać reprezentację liczbową na podstawie autorefleksji osobnika wartościującego, który starałby się rzetelnie określić własną decyzję w odpowiednio dobranych sytuacjach fikcyjnych ${ }^{23}$ ". Stąd można wyciągnąć wnioski, że przeprowadzenie jakiegokolwiek badania związanego z teorią decyzji wydaje się niemożliwe. Jednak Szaniawski twierdzi, że „nie likwiduje to oczywiście przybliżonej stosowalności tego modelu, który zresztą i w innych dziedzinach badań nad postępowaniem ludzkim pełni taką właśnie rolę, funkcjonuje mianowicie jako schemat, którego parametrom nadaje się wartości liczbowe w trybie oszacowania dalekiego od dokładności ${ }^{24}$ ".

Stąd także wynika zastosowanie modelów decyzyjnych w teorii ${ }^{25}$ do badania zagadnień etycznych. Szaniawski zaznacza także, że pojęcie decyzji jest pragmatyczne, nie tylko przez wzgląd na możliwość zastosowania w praktyce. Ale przede wszystkim, przez wartościowanie działań podjętych w wyniku decyzji. „Można stwierdzić, że aparatura pojęciowa decyzji jest szczególnie dobrze przystosowana do

22 K. Szaniawski, Teoria decyzji a etyka, dz. cyt., 10.

23 Tamże, 11.

24 Tamże.

25 Zob. J. Syski, dz. cyt., 79-82. 
nauk stosowanych. Jeżeli bezpośrednim celem badań jest ulepszenie pewnej konkretnej decyzji, która ma być podjęta, to wszystkie składniki aparatury pojęciowej [teorii decyzji - przypis mój L.M.] znajdują naturalną interpretację ${ }^{26}$. Sprowadzalność konsekwencji czynów (pod względem wartości etycznej) do liczb porównywalnych jednowymiarowo, czyli dających się rozmieścić na jednej skali wartości, jest bardzo wątpliwe. Dlatego Szaniawski dostrzega trudności w zastosowaniu decyzji etycznej. „Trudność decyzji etycznej pochodzi m.in. stąd, że porównawcza ocena konsekwencji czynów różnie na ogół wypada w świetle różnych norm postępowania, akceptowanych przez decydenta. Normy te wyznaczają więcej niż jedną skalę wartościowań i jest otwartym problemem, czy można je zredukować do jednego wymiaru ${ }^{27}$. Jest to oczywisty konflikt wartości, gdy przypisujemy danej sytuacji konsekwencje dające się opisać dwóm lub więcej liczbom. I wtedy założenia modelu ulegają zmianie i nie dają się zastosować. „Powstaje pytanie, czy dałoby się coś powiedzieć na temat racjonalnego podejmowania decyzji przy (...) zastąpieniu wartościowania jednowymiarowego przez wielowymiarowe ${ }^{28}$ ?"

Według Szaniawskiego problem ten nie ma rozwiązania, przynajmniej w warunkach niepewności co do skutków. Ale pozwala na lepsze uprzytomnienie sobie, czym tak na prawdę jest proces decyzyjny przy etycznych założeniach i które jego elementy wymagaja dokładniejszego zbadania.

\section{PRZYKŁADY ZASTOSOWANIA APARATU TEORIO-DECYZYJNEGO DO ZAGADNIEŃ ETYCZNYCH}

Moje rozważania są jedynie wstępem do dalszych badań możliwości praktycznych zastosowań teorii decyzji do analizy podmiotu.

26 K. Szaniawski, Informacja i decyzja jako narzędzia filozofii nauki, dz. cyt., 351.

27 Tenże, Teoria decyzji a etyka, dz. cyt., 11.

28 Tamże. 
W takim zakresie chciałabym, aby związek teorii decyzji z etyką był nadal pogłębiony.

By wskazać przydatność aparatury pojęciowej teorii decyzji w praktyce, posłużę się przykładami zaczerpniętymi z nauk prawnych i medycyny. To zagadnienie jest przedmiotem zainteresowania Szaniawskiego w artykule pt. Granice logiki decyzji z 1988 roku (jednym $z$ ostatnich napisanych przez uczonego, zatem prezentującego jego poszerzone poglądy tego zagadnienia).

Według Szaniawskiego decyzja medyczna rozważana może być na gruncie pytania: czy praktyka medyczna przebiega zgodnie z zaleceniami logiki decyzji? Szaniawski wskazuje, że jeżeli przebiega ona według schematu:

1) diagnoza,

2) podjęcie terapii optymalnej,

to są bardzo różne warianty zachowań, jakie może podjąć nie tylko lekarz, ale także sam pacjent. Wszelkie sposoby leczenia są dopasowane do konkretnych chorób. Jednak nie zawsze lekarz, czy pacjent, jest pewny diagnozy. Albo też leczenie jest skuteczne w jednym aspekcie, a w innym szkodzi. Mimo tego, że leczenie nie daje gwarancji wyleczenia, to jednak pacjent je rozpoczyna - świadomie sobie szkodząc. Dlaczego podejmuje taką decyzję? Albo jak zareaguje pacjent na dane leczenie - przecież każdy organizm ludzki jest inny? Te wątpliwości i zastrzeżenia potwierdzają tylko, że często jest tak, że decyzje medyczne w ogóle nie kierują się logiką decyzji.

Szaniawski stwierdza, że w sytuacji wyboru decydent wybierać musi to działanie, które przynosi skutki o najwyższej wartości przeciętnej (tzw. maksymalizacja przeciętnej użyteczności). Dzieje się tak, gdy mamy do czynienia $\mathrm{z}$ sytuacją $\mathrm{w}$ warunkach ryzyka. Ale warunkiem tutaj jest to, że wszelkie konsekwencje alternatywnych sytuacji są możliwe i znane decydentowi. Natomiast nie ma pewności, która $\mathrm{z}$ tych sytuacji zajdzie. Znany jest decydentowi zbiór możliwych do wyboru działań optymalnych. Wnioskować zatem można, że choć decyzje medyczne powinny przebiegać według racjonalnych 
przesłanek i maksymalizacji pożądanych skutków, to w praktyce tak się nie dzieje. „Wydaje mi się w każdym razie pewne, że w opisie sposobu podejmowania decyzji [dotyczącej decyzji medycznych - dopisek mój L.M.] (...) najpierw diagnoza, następnie to, co optymalne, przy założeniu, że jest ona prawdziwa ${ }^{29}$. Maksymalizacja przeciętnej użyteczności zostaje wyrugowana. Dzieje się tak, ponieważ brakuje czasu na poszukiwania najlepszego sposobu leczenia danej choroby. A odwlekanie w czasie leczenia i niepodejmowanie diagnozy, tylko $\mathrm{z}$ tego powodu, że prawdopodobieństwo wybranej diagnozy nie jest dostatecznie wysokie, by być zbliżone do podejmowania decyzji w warunkach pewności, skutkuje niewyleczeniem chorego pacjenta.

Decyzje medyczne, przynajmniej te podjęte przez lekarzy, nie kierują się logiką decyzji. Wolno jednak pacjentowi samemu decydować o sposobach leczenia siebie samego. Co w takim wypadku z zastosowaniem reguł logiki decyzji? Szaniawski zauważa, że być może u pacjenta podejmowanie decyzji jest bliższe logice decyzji. „W tym sensie, że pacjent waży wartościowanie możliwych konsekwencji za pomocą prawdopodobieństwa, a następnie maksymalizuje taką sumę ważoną. Niewiele wiemy o rzeczywistych sposobach rozwiązywania tak dramatycznych problemów $w^{30}$. Etyczne dylematy i rzeczywiste problemy podmiotu z całą pewnością wykraczają poza obszar wyznaczony logiką. Granicą logiki są sytuacje trudne, związane z chorobami, gdzie podmiot sam o sobie nie jest w stanie wnioskować, że postąpi według konkretnego schematu, według konkretnej decyzji. Logika, racjonalność w sytuacjach granicznych dla człowieka, zostaja w tyle za jego instynktami.

W decyzji prawnej Szaniawski również nawiązuje do logiki decyzji. Schemat podejmowania decyzji jest następujący: 1) stwierdzenie stanu faktycznego (stanu świata, jaki rzeczywiście nastąpił), następnie 2) podjęcie decyzji, która jest najlepsza (najbardziej użyteczna) przy

29 K. Szaniawski, Granice logiki decyzji, Studia Filozoficzne (1988)6-7(271-272), 312.

30 Tamże, 313. 
założeniu ustalonego wcześniej stanu świata. W systemie prawnym ważne jest to, by decyzje były podejmowane bez żadnych wątpliwości. Oczywiście tyczy się to także decyzji medycznych. Jednak w prawie istnieją konkretne normy, które nie pozwalają uzależniać wyroku od ewentualnych wątpliwości, jakie sąd mógłby żywić co do stanu faktycznego związanego ze sprawą. „Użyteczność skutków decyzji prawnej można wyznaczać w zależności od rozmaitych czynników, takich jak zgodność orzeczenia ze stanem faktycznym, zgodność z literą prawa, spodziewane skutki w świadomości społecznej itp. Oczywiście ustalenie rzeczywistego stanu świata z całkowitą pewnością nie zawsze jest możliwe. Branym pod uwagę możliwościom (...) można przypisywać co najmniej subiektywne prawdopodobieństwa ${ }^{31}$. Prawdopodobieństwa nie są wykorzystywane w podejmowaniu decyzji prawnych w sposób, jaki proponuje logika decyzji, ponieważ nie wolno wyroków sądowych uzależniać od jakichkolwiek wątpliwości. $\mathrm{W}$ anglosaskim prawie karnym występuje postulat „ponad rozsądną wątpliwość", który mówi, że choć dopuszczalne są wątpliwości, muszą one być minimalne. „Inaczej mówiąc, hipoteza winy może być przyjęta tylko wówczas, gdy jej prawdopodobieństwo jest praktycznie równe 1 . Ale wtedy nie jest kwestionowana ${ }^{32}$ ".

W logice decyzji nie ma czegoś takiego jak „uznanie” zdania. Zamiast „uznania” występuje rozkład prawdopodobieństwa w zbiorze. „»Uznać zdanie $\mathrm{S}$ « może znaczyć jedynie »przypisać zdaniu $\mathrm{S}$ prawdopodobieństwo równe 1 « (...). $Z$ tego punktu widzenia problem decyzji, przed którym stoi sąd, nie może być interpretowany jako wybór między "przyjęciem« lub »odrzuceniem« hipotezy - powiedzmy $W$ - winy, ponieważ rozkład prawdopodobieństwa na zbiorze $\{W$, non- $W\}$ nie daje się przekształcić w zero-jedynkowy przez przyjęcie założenia, że jakiś typ błędu ma niezmiernie niską użyteczność

31 Szersza analiza przydatności zagadnień teorii decyzji do analizy zachowań podmiotu została zawarta w artykule: K. Szaniawski, Granice logiki decyzji, dz. cyt.

32 Tamże, 314. 
(...) $)^{33}$. Szaniawski zakłada, że podejmowanie decyzji w prawie, podobnie jak w medycynie, zachodzi przez stanowcze uznawanie hipotez lub przez maksymalizację wartości, a nie przez stosowanie logiki decyzji. Stąd też jego wskazanie, że choć logika decyzji może być uniwersalnie stosowalna, to jednak uniwersalnie stosowana nie jest. „Logika decyzji obywa się bez pojęcia uznawania zdań. Można powiedzieć, że omija to pojęcie przez uzależnienie wyboru działania od użyteczności oraz rozkładu prawdopodobieństwa. Tymczasem w praktyce prawniczej (...) wyraźne uznanie zdania, na którym opiera się wyrok, jest konieczne. Takie sądy nie są moralnie neutralne, z tej więc przyczyny sąd musi je uznać lub odrzucić. I nie wolno mu w tej kwestii zadowolić się prawdopodobieństwem (...). Formalne orzeczenie w tej sprawie musi być kategoryczne $(. . .)^{34 "}$.

Szaniawski podkreśla, że droga dochodzenia do decyzji przez optymalizację na podstawie przyjętej hipotezy jest aprobowana w logice decyzji. Jednak w codziennych decyzjach prawdopodobieństwo nie jest przewodnikiem podmiotu. W takich momentach jest nią wiedza, co do której zakładamy, że jest prawdziwa. Nie kwestionujemy jej, dopóki skutki decyzji są poważniejsze lub gdy brakuje nam wiedzy $\mathrm{w}$ danym temacie. Wtedy zaczynamy myśleć $\mathrm{w}$ kategoriach prawdopodobieństwa. „Granice logiki decyzji wyznaczone są bądź przez praktyczną wygodę (jak w codziennych decyzjach nacechowanych niewysokim ryzykiem), bądź też przez konieczność uzależnienia decyzji od wyraźnie uznanych zdań (jak w medycynie lub prawie) ) $^{35}$. Jestem przekonana, że jest to pewne nowatorskie zrozumienie pojęcia decyzji przez Szaniawskiego, który koncentruje się nie na celu, ale na podmiocie działań.

33 Tamże.

34 Tamże, 315.

35 Tamże. 


\section{ZAKOŃCZENIE}

Związki teorii decyzji z etyką są niezaprzeczalne. Po pierwsze, nie tylko wówczas, gdy mówimy o wielowymiarowości wartości lub samym problemie kierowania się wartościami w decyzji. Ale - jak wskazuje Szaniawski - dostrzeżenie etycznych problemów w pewnych działach teoretycznych teorii decyzji, jak sprawiedliwy podział czy zbiorowe podejmowanie decyzji, dodatkowo wzmacniają związek teorii decyzji z etyką i „mogą być nazwane - z niewielką dozą przesady - uprawianiem etyki środkami matematycznymi ${ }^{36 "}$. Po drugie, w rozumieniu Szaniawskiego znaczenie pojęcia racjonalności nie tylko odnosi się do teorii decyzji, ale wiąże działania podmiotu z decyzją. Racjonalność spaja zagadnienia etyczne, jak np. ważność wyboru podmiotu czy hierarchizacja wartości do danego celu, z pewnymi optymalnymi sposobami wyboru (maksymalizacja). Tym sposobem odgrywa znaczącą rolę w refleksji etycznej. I wreszcie, po trzecie, Szaniawski proponuje rozwiązanie, w którym ,zaznajomienie się $\mathrm{z}$ aparaturą pojęciową teorii decyzji jest pouczające dla badaczy ludzkich zachowań (...). A etycy badają m.in. właśnie postępowanie ludzkie ${ }^{37 ”}$. Bezpośrednio nawołuje do poszukiwania związków teorii decyzji z etyką, nie tylko na poziomie aparatury pojęciowej, ale także na poziomie metaetycznym - badania natury człowieka.

Szaniawski zwraca uwagę na istotną własność pojęcia decyzji, które zawiera dwa elementy: wybór działania i postanowienie ${ }^{38}$ jego realizacji. Co więcej, decydent dokonuje wyboru z konkretnego zbioru wartości, ale nie jest zdeterminowany co do celu. Zatem decyzja jest zrelatywizowana do celu, choć cel determinuje zbiór wartości, jakimi kieruje się podmiot, a sam wybór uwzględnia przekonania i wartościowanie decydenta. Zaznaczając przy tym,

36 K. Szaniawski, Teoria decyzji a etyka, dz. cyt., 17.

37 Tamże.

38 Zob. Arystoteles, Etyka Nikomachejska, Księga III, tłum. D. Gromska, Warszawa 2002. 
że wartościowanie i preferencje, które są udziałem podmiotu, nie zmieniają się co chwilę, nie ulegają dewaluacji, natomiast cel może być różny, zmienny. Dlatego rozumienie pojęcia decyzji nie wiąże się ściśle $\mathrm{z}$ celem, ale $\mathrm{z}$ podmiotem: $\mathrm{z}$ refleksyjnością osoby, która posiada pewien charakter i zarazem kształtuje go właśnie podczas podejmowania decyzji. Ta prawidłowość skutkuje nietradycyjnym ujęciem zagadnienia problemu decyzji: nie cel, który determinuje decyzję, ale podmiot, który wyznacza cel.

Wszystkie wyróżnione elementy, jak: praktyczność, słuszność, racjonalność mają ścisły związek z podejmowaniem decyzji i jej wpływem na samego człowieka. W etyce podejmowanie decyzji to problem istotny filozoficznie. W konkretnych wyborach, decyzjach ważne jest wskazanie na zachowanie człowieka, formułowane cele, środki i motywy. Cały proces decyzyjny pokazuje, kim jest człowiek. Włączenie teorii decyzji do analizy podmiotu, osobowości, definiowania tożsamości pozwala na wielostronne poznanie człowieka (w działaniu i poprzez działanie). To, jakimi jesteśmy ludźmi, nie jest bez wpływu na to, jakie decyzje podejmujemy. Ale też wybory, jakimi warunkujemy nasze działania, definiują nasze człowieczeństwo.

\section{BIBLIOGRAFIA}

Amsterdamski S., Woleński J., Wstęp, w: K. Szaniawski, O nauce, rozumowaniu i wartościach, wybrał i opracowal J. Woleński, PWN, Warszawa 1994.

Arystoteles, Etyka Nikomachejska, Księga III, tłum. z grec. D. Gromska, PWN, Warszawa 2002.

Blegvad M., The Content and Status of Rationality Assumptions in Social Science, Danish Yearbook of Philosophy (1978)15, 55-67.

Gasparski W., Klemensa Szaniawskiego teoria decyzji w zarysie, Prakseologia (2006)146, 13-24.

Jak wywiad, to wywiad..., red. I. Heppen, A. Negri, Przegląd Filozoficzny- Nowa Seria 20(2011)2(78), 297-307.

Syski J., Czuwanie rozumu, Czytelnik, Warszawa 1979, 79-92.

Szaniawski K., Granice logiki decyzji, Studia Filozoficzne (1988)6-7(271-272), 309-315. 
Szaniawski K., O nauce, rozumowaniu i wartościach, wybrał i opracował J. Woleński, PWN, Warszawa 1994.

Szaniawski K., Kilka uwag o kryterium racjonalnego podejmowania decyzji, w: O nauce, rozumowaniu $i$ wartościach, wybrał i opracował J. Woleński, PWN, Warszawa 1994, 172-187.

Szaniawski K., Informacja a decyzja, w: O nauce, rozumowaniu i wartościach, wybrał i opracował J. Woleński, PWN, Warszawa 1994, 253-266.

Szaniawski K., Kryteria podejmowania decyzji, w: O nauce, rozumowaniu $i$ wartościach, wybrał i opracował J. Woleński, PWN, Warszawa 1994, 286-304.

Szaniawski K., Informacja i decyzja jako narzędzia flozofii nauki, w: O nauce, rozumowaniu $i$ wartościach, wybrał i opracował J. Woleński, PWN, Warszawa 1994, 345-356.

Szaniawski K., Filozofia podejmowania decyzji, w: O nauce, rozumowaniu i wartościach, wybrał i opracował J. Woleński, PWN, Warszawa 1994, 431-444.

Szaniawski K., Racjonalność jako wartość, Studia Filozoficzne (1983)5-6(210-211), 7-15.

Szaniawski K., Teoria decyzji a etyka, Etyka (1967)2, 7-17.

\section{KLEMENS SZANIAWSKI ON THE POSSIBILITY OF APPLICATION OF DECISION THEORY TO ETHICAL ISSUES}

Abstract. Klemens Szaniawski, who is associated with the philosophy of science and logic, in his deliberations is also dealing with decision theory and indicates to its connections with ethic. Starting from conceptual and linguistic links between decision theory and ethics, Szaniawski is looking for their further connection.

In the article various applications of decision theory are exhibited in relation to shaping the personality of a man. Firstly, it is noted that the concept of "rationality" is this element which bind ethic with the decision-making process.

Secondly, a decision contains two elements: the choice of action and its implementation. The decision is relative to an objective, and the objective determines the aggregation, and the selection takes into account the beliefs and values of decision-maker. Thirdly, to understand the concept of decision, it should be associated with a person who has a character and it is molded during making decisions. Moreover, in the specific decisions of the person appear objectives, capabilities and motives. Therefore, the inclusion of decision theory to analyze the personality of the person and defining identity allows for multi-sided human knowledge.

The new look at the issue of the whole decision-making process, indicated the possibility of a pragmatic application of the concepts of decision theory in ethics. To determine the 
suitability of conceptual apparatus decision theory in practice, illustrative examples drawn from science: law and medicine.

Keywords: Decision, Decision theory, ethics, rationality, using decision in ethics, decision as a value, ethical person

LUCYNA MAJEWSKA

L.Majewska@ifil.uz.zgora.pl

Uniwersytet Zielonogórski, Instytut Filozofii

al. Wojska Polskiego 71A, 65-762 Zielona Góra

DOI: 10.21697/spch.2016.52.2.06 